\title{
PENGARUH EFIKASI DIRI TERHADAP PRESTASI BELAJAR MATEMATIKA MELALUI KETERLIBATAN BELAJAR SISWA KELAS XI SMA NEGERI 2 BULUKUMBA
}

\author{
Muhammad Awal Nur \\ STIMIK Bina Adinata, Bulukumba, Indonesia
}

awalnur10@gmail.com

\begin{abstract}
Abstrak
Penelitian ini bertujuan untuk mengetahui (1) Seberapa besar pengaruh efikasi diri terhadap keterlibatan belajar matematika siswa kelas XI SMA Negeri 2 Bulukumba; (2) Seberapa besar pengaruh efikasi diri terhadap hasil belajar matematika siswa kelas XI SMA Negeri 2 Bulukumba; (3) Seberapa besar pengaruh keterlibatan belajar matematika terhadap hasil belajar matematika siswa kelas XI SMA Negeri 2 Bulukumba; (4) Seberapa besar pengaruh tidak langsung efikasi diri terhadap prestasi belajar matematika melalui keterlibatan belajar siswa kelas XI SMA Negeri 2 Bulukumba. Metode Penelitian yang digunakan adalah penelitian ex-post facto yang bersifat kausalitas. Populasi dalam penelitian ini adalah siswa kelas XI SMA Negeri 2 Bulukumba dengan jumlah sampel 144 siswa. Pengumpulan data dilakukan dengan menggunakan instrumen yang berupa skala efikasi diri, skala keterlibatan belajar dan hasil ulangan semester gajil tahun ajaran 2020/2021 mata pelajaran matematika. Teknik analisis data yang digunakan dalam penelitian ini yaitu statistik inferensial dengan menggunakan analisis SEM. Hasil penelitian menunjukkan bahwa (1) efikasi diri berpengaruh positif dan signifikan terhadap keterlibatan belajar matematika dengan besarnya pengaruh 1,130 atau $113 \%$; (2) efikasi diri berpengaruh positif dan signifikan terhadap prestasi belajar matematikan dengan besarnya pengaruh 0,523 atau $52,3 \%$; (3) keterlibatan belajar matematika tidak berpengaruh secara signifikan terhadap prestasi belajar matematika; (4) tidak ada pengaruh positif dan signifikan efikasi diri melalui keterlibatan belajar matematika terhadap prestasi belajar matematika.
\end{abstract}

Kata Kunci: Efikasi Diri; Keterlibatan Belajar; Hasil Belajar Matematika.

Diterbitkan Oleh:

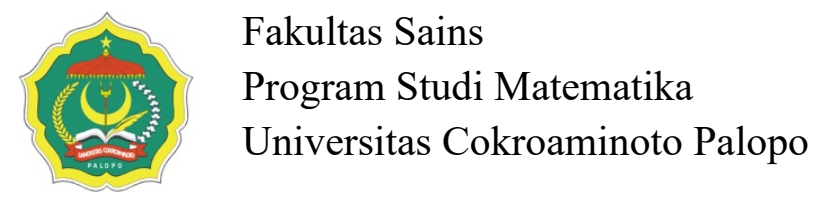

Copyright (C) 2021 The Author (s)

This article is licensed under CC BY 4.0 License

\section{(cc) BY}




\section{PENGARUH EFIKASI DIRI TERHADAP PRESTASI BELAJAR MATEMATIKA MELALUI KETERLIBATAN BELAJAR SISWA KELAS XI SMA NEGERI 2 BULUKUMBA}

\section{Pendahuluan}

Matematika disebut sebagai ratunya ilmu yang merupakan kunci utama dari pengetahuan pengetahuan lain yang dipelajari di sekolah. Pentingnya matematika tidak dibarengi peningkatan prestasi dalam bidang studi ini. Kenyataannya prestasi belajar matematika siswa di Indonesia menunjukkan hasil yang kurang memuaskan.

Hal tersebut dapat dilihat berdasarkan hasil ujian nasional tahun 2019 tingkat SMA secara nasional rerata nilai mata pelajaran matematika untuk jurusan IPA dan IPS adalah 39,37 dan 34,35 (Pusat Penilaian Kemendikbud, 2019) terendah diantara mata pelajaran lain yang diujiankan. Selain itu, hasil studi PISA 2018 yang dirilis oleh OECD menunjukkan bahwa kemampuan siswa Indonesia dalam matematika tergolong low performance dengan skor ratarata 379 (Kemendikbud, 2018). Prestasi belajar matematika siswa di Sekolah Menengah Atas (SMA) Negeri 2 Bulukumba juga masih tergolong rendah. Hal ini dilihat dari hasil ujian nasional tahun 2019 rerata nilai mata pelajaran matematika sebesar 32,24 (Pusat Penilaian Kemendikbud, 2019).

Rendahnya prestasi belajar matematika siswa dipengaruhi oleh banyak faktor. Salahsatu faktor penyebabnya adalah dari dalam diri siswa yaitu mengalami masalah dalam mempelajari matematika dan faktor lingkungan yang tidak mendukung siswa untuk belajar matematika secara maksimal. Menurut Slameto mengemukakan bahwa faktor-faktor yang mempengaruhi belajar digolongkan ke dalam dua jenis yaitu faktor internal dan faktor eksternal. Faktor internal adalah faktor yang ada dalam individu yang sedang belajar Sedangkan, faktor eksternal adalah faktor yang berada di luar individu yang sedang belajar (Slameto,2010).

Selain itu, ada beberapa faktor yang mempengaruhi prestasi dalam belajar yaitu faktor afektif. Faktor afektif mengacu pada berbagai perasaan atau kecendrungan hati seseorang yang tidak berkaitan dengan kemampuan berpikir antara lain keyakinan pemecahan masalah, sikap terhadap matematika, kecemasan matematika dan efikasi diri matematika (Alam,2018).

Efikasi diri adalah keyakinan individu mengenai kemampuan dirinya dalam melakukan tugas atau tindakan yang diperlukan untuk mencapai hasil tertentu. Siswa yang memiliki efikasi diri yang positif maka akan berdampak pada pencapaiannya dalam belajar. Bandura mengemukakan bahwa "mathematics self-efficacy is defined as an individual's beliefs or 
perceptions with respect to his or her abilities in mathematics (Alam,2018). Lebih lanjut, Bandura menyatakan bahwa efikasi diri matematika siswa berasal dari empat sumber yang terdiri atas personal experience, vicarious experience, social persuasion dan physiological \& emotion state (Alam, 2018).

Mastery experience berkaitan dengan pengaruh keberhasilan siswa akan tingkatan efikasi diri matematis siswa serta pengalaman kegagalan akan merendahkan efikasi diri matematis siswa. Vicarious experience berkaitan dengan pengalaman keberhasilan siswa lain yang mempunyai keahlian mirip dalam melakukan tugas dengan siswa tersebut untuk meningkatkan efikasi diri matematikanya. Social persuasion berkaitan dengan data yang di informasikan secara verbal yang bisa mempengaruhi serta meyakinkan siswa pada tugas yang diberikan. Physiological \& emotion state berkaitan dengan kecemasan ataupun tekanan pikiran yang dirasakan seorang yang berhubungan dengan kegagalan (Alam,2018)

Beberapa hasil penelitian yang telah dilakukan sebelumnya menunjukkan bahwa efikasi diri matematika berpengaruh terhadap pencapaian atau keberhasilan siswa dalam belajar antara lain : Hasil penelitian Sukoco, dkk menunjukkan bahwa Mathematics Self-Efficacy (MSE) berpengaruh terhadap hasil UN siswa (Sukoco, 2018). Selain itu, hasil penelitian Ozkal (2019) menunjukkan bahwa self-efficacy berhubungan secara signifikan dengan prestasi belajar matematika melalui keterlibatan perilaku dan afektif dalam belajar matematika. Hasil Penelitian Yurt (2014) menunjukkan bahwa Self-Efficacy berhubungan secara signifikan terhadap prestasi belajar siswa kelas 7 di Sekolah Konya.

Keterlibatan belajar adalah keterlibatan siswa dalam proses pembelajaran baik dalam kegiatan akademik maupun non akademik yang ditinjau melalui perilaku, emosi, dan kognitif yang ditampilkan oleh siswa di lingkungan sekolah dan kelas (Suryanti, et al, 2019). Selain itu, Keterlibatan belajar adalah kemauan dan upaya siswa untuk secara aktif terlibat dalam kegiatan sekolah yang berkontribusi pada hasil belajar yang memuaskan. Siswa dengan keterlibatan belajar yang tinggi akan mencapai nilai yang lebih tinggi dari siswa dengan tingkat keterlibatan rendah. Keterlibatan belajar siswa terdiri atas tiga sumber antara lain: keterlibatan kognitif, keterlibatan afektif dan keterlibatan perilaku. Keterlibatan afektif berkaitan dengan rasa memiliki dan penerimaan tujuan (Kong, et.al, 2003)

Hasil penelitian Fung, et. al (2018) menunjukkan bahwa keterlibatan belajar berpengaruh positif terhadap hasil belajar matematika. Selain itu, Jie, et al (2020) menunjukkan bahwa keterlibatan belajar matematika siswa SMP di China berhubungan secara signifikan dengan prestasi belajar matematika pada keterlibatan belajar kognitif. Hasil penelitian Lei et al (2018) menunjukkan bahwa ada korelasi yang cukup kuat dan positif antara keterlibatan belajar 
siswa dengan prestasi akademik.

\section{Metode Penelitian}

Penelitian ini termasuk penelitian ex-post facto yang bersifat kausalitas. Penelitian expost facto dirancang untuk menerangkan adanya hubungan sebab akibat antar variabel. Variabel penelitian ini adalah Efikasi Diri Matematika, Keterlibatan Belajar Matematika dan Prestasi Belajar Matematika.

Populasi dalam penelitian ini adalah seluruh siswa kelas XI SMA Negeri 2 Bulukumba tahun pelajaran 2020/2021. Metode pengambilan sampel yang digunakan dalam penelitian ini adalah menggunakan teknik random sampling dengan jumlah sampel 144 siswa. Pengumpulan data dilakukan dengan menggunakan instrumen yang berupa skala efikasi diri matematika, skala keterlibatan belajar matematika dan hasil belajar matematika diperoleh dari nilai raport matematika siswa semester ganjil tahun pelajaran 2020/2021.

Instrumen penelitian disebarkan secara online melalui grup whatshaap. Skala efikasi diri matematika dibuat dengan mengadaptasi Mathematics Self-Efficacy Scale yang dirancang oleh Usher dan Pajares (2009) dengan 24 item pernyataan yang terdiri atas 6 item pernyataan personal experience, 6 item pernyataan vicarious experience, 6 item pernyataan social persuasion, dan 6 item pernyataan physiological \& emotion state dengan 4 pilihan jawaban yaitu 4 = Sangat Sesuai/Sangat Setuju, 3 = Sesuai/Setuju, 2 = Tidak Sesuai/ Tidak Setuju, $1=$ Sangat Tidak Sesuai/ Sangat Tidak Setuju. Skala keterlibatan belajar matematika dibuat dengan mengadaptasi Student engagement in mathematics scale yang dirancang oleh Rimm-Kaufman (2017) dengan 13 item pernyataan yang terdiri atas 4 item pernyataan cognitive, 4 item pernyataan social dan 5 item pernyataan emotional dengan 4 pilihan jawaban yaitu $4=$ Sangat Sesuai/Sangat Setuju, 3 = Sesuai/Setuju, 2 = Tidak Sesuai/ Tidak Setuju, $1=$ Sangat Tidak Sesuai/ Sangat Tidak Setuju.

Teknik analisis data yang digunakan dalam penelitian ini adalah statistik inferensial dimaksudkan untuk analisis dan validasi model yang diusulkan serta pengujian hipotesis dengan menggunakan teknik analisis Structural Equation Modeling(SEM) dengan perangkat AMOS (Analysis Of Moment Structure) IBM versi 20.0 dan SPSS IBM versi 20.0.

\section{Hasil dan Pembahasan}

Hasil analisis Structural Equation Modeling (SEM) dengan menggunakan perangkat AMOS (Analysis Of Moment Structure) IBM versi 20.0 diperoleh hasil sebagai berikut: 


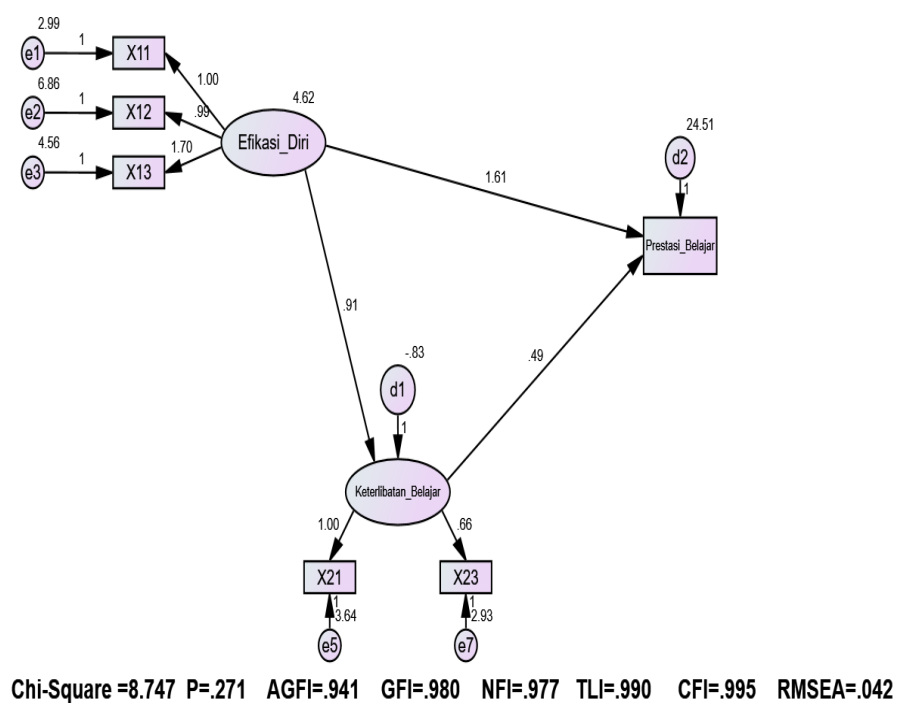

Gambar. Path Analysis

Tabel. 1 Regression Weights Model Persamaan Struktural Tahap Akhir

\begin{tabular}{lllrrrr}
\hline & Path & & Estimate & S.E. & C.R. & P \\
\cline { 2 - 7 } Keterlibatan_Belajar & $<---$ & Efikasi_Diri & 0.909 & 0.099 & 9.192 & $* * *$ \\
Prestasi_Belajar & $<---$ & Efikasi_Diri & 1.612 & 0.760 & 2.121 & 0.034 \\
Prestasi_Belajar & $<---$ & Keterlibatan_Belajar & 0.491 & 0.855 & 0.575 & 0.566 \\
\hline
\end{tabular}

Tabel. 2 Standardized Regression Weights Model Persamaan Struktural Tahap Akhir

\begin{tabular}{lrrr}
\hline & \multicolumn{2}{c}{ Path } & Estimate \\
\hline Keterlibatan_Belajar & $<---$ & Efikasi_Diri & 1.130 \\
Prestasi_Belajar & $<---$ & Efikasi_Diri & 0.523 \\
Prestasi_Belajar & $<---$ & Keterlibatan_Belajar & 0.128 \\
\hline
\end{tabular}

Tabel. 3 Standardized Direct Effects

\begin{tabular}{lrr}
\hline \multicolumn{1}{c}{ Variabel } & Efikasi Diri & Keterlibatan_Belajar \\
\hline Keterlibatan_Belajar & 1.130 & 0.000 \\
Prestasi_Belajar & 0.523 & 0.128 \\
\hline
\end{tabular}

Tabel. 4 Standardized Indirect Effects

\begin{tabular}{crr}
\hline Variabel & Efikasi Diri & Keterlibatan Belajar \\
\hline Keterlibatan_Belajar & 0.000 & 0.000 \\
Prestasi_Belajar & 0.145 & 0.000 \\
\hline
\end{tabular}




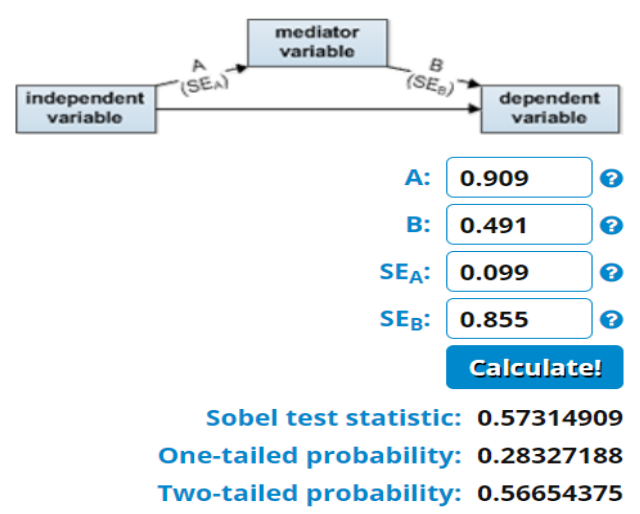

Gambar 2. Tes Sobel Online Signifikan Pengaruh Tidak Langsung

Berdasarkan hasil analisis data dan Tabel 1, maka hasil pengujian hipotesis penelitian dinyatakan sebagai berikut.

\section{a. Pengaruh langsung efikasi diri terhadap Keterlibatan belajar matematika.}

Hipotesis statistik pertama yang akan diuji adalah:

$$
H 0: \gamma_{11}=0 \text { melawan } H 1: \gamma_{11}>0
$$

dimana H1 menyatakan bahwa ada pengaruh langsung yang positif dan signifikan dari efikasi diri terhadap keterlibatan belajar matematika pada taraf signifikansi 0,05. Sebagaimana ditunjukkan dalam Tabel 1 dan Tabel 2, diperoleh hasil estimasi $\gamma_{11}=1,130$ yang positif dengan nilai $p=0,000<\alpha=0,05$ yang siginifikan. Ini berarti bahwa $\mathrm{H}_{0}$ ditolak pada taraf signifikansi 0,05 . Jadi ada pengaruh positif dan signifikan efikasi diri terhadap keterlibatan belajar matematika pada taraf signifikansi 0,05 .

\section{b. Pengaruh langsung efikasi diri terhadap Prestasi belajar matematika.}

Hipotesis statistik kedua yang akan diuji adalah

$$
H 0: \gamma_{12}=0 \text { melawan } H 1: \gamma_{12}>0
$$

dimana H1 menyatakan bahwa ada pengaruh langsung yang positif dan signifikan dari efikasi diri terhadap prestasi belajar matematika pada taraf signifikansi 0,05. Sebagaimana ditunjukkan dalam Tabel 1 dan 2, diperoleh hasil estimasi $\gamma_{12}=0,523$ yang positif dengan nilai $p=0,034<0,05$ yang signifikan. Ini berarti bahwa H0 ditolak pada taraf signifikansi 0,05 . Jadi ada pengaruh positif dan signifikan efikasi diri terhadap prestasi belajar matematika pada taraf signifikansi 0,05 .

c. Pengaruh langsung Keterlibatan belajar matematika terhadap Prestasi Belajar

\section{Matematika}

Hipotesis statistik ketiga yang akan diuji adalah

$$
H 0: \beta_{21}=0 \text { melawan } H 1: \beta_{21}>0
$$


dimana $\mathrm{H} 1$ menyatakan bahwa ada pengaruh langsung yang positif dan signifikan dari keterlibatan belajar matematika terhadap prestasi belajar matematika pada taraf signifikansi 0,05. Sebagaimana ditunjukkan dalam Tabel 1 dan 2 , diperoleh hasil estimasi $\beta_{21}=0,128$ yang positif dengan nilai $p=0.566>\alpha=0,05$ yang tidak signifikan. Ini berarti bahwa H1 ditolak pada taraf signifikansi 0,05 . Jadi tidak ada pengaruh positif dan signifikan keterlibatan belajar matematika terhadap prestasi belajar matematika pada taraf signifikansi 0,05 .

\section{d. Pengaruh tidak langsung Efikasi diri melalui Keterlibatan Belajar Matematika terhadap Prestasi Belajar Matematika}

Hipotesis statistik keempat yang akan diuji adalah

$$
\text { H0: } \beta_{21} \gamma_{11}=0 \text { melawan } H 1: \beta_{21} \gamma_{11}>0
$$

dimana H1 menyatakan bahwa ada pengaruh tidak langsung yang positif dan signifikan dari efikasi diri melalui keterlibatan belajar matematika terhadap prestasi belajar matematika pada taraf signifikansi 0,05. Sebagaimana ditunjukkan dalam Tabel 4 dan gambar 1 diperoleh hasil estimasi $\beta_{21} \gamma_{11}=0,145$ yang positif dengan nilai $p=0,566>\alpha=0,05$ yang tidak signifikan. Ini berarti bahwa H1 ditolak pada taraf signifikansi 0,05. Jadi tidak ada pengaruh positif dan signifikan dari efikasi diri melalui keterlibatan belajar matematika terhadap prestasi belajar matematika pada taraf signifikansi 0,05 .

Berdasarkan hasil uji hipotesis diperoleh bahwa efikasi diri berpengaruh positif dan signifikan terhadap keterlibatan belajar matematika pada taraf signifikansi 0,05. Besarnya pengaruh efikasi diri terhadap keterlibatan belajar matematika adalah 1,130 atau $113 \%$. Hasil ini didukung hasil penelitian sebelumnya yang dilakukan oleh Yavuz Sökmen (2021) menyatakan bahwa efikasi diri secara positif memprediksi kognitif, emosional, perilaku (keterlibatan belajar) dan keterlibatan agen pada siswa di turki.

Hasil uji hipotesis menunjukkan bahwa efikasi diri berpengaruh positif dan signifikan terhadap prestasi belajar matematikan pada taraf signifikansi 0,05. Besarnya pengaruh efikasi diri terhadap prestasi belajar matematika siswa adalah 0,523 atau 52,3\%. Hasil ini didukung oleh hasil penelitian yang dilakukan oleh Sukoco, dkk (2018) menunjukkan bahwa Mathematics Self-Efficacy (MSE) berpengaruh terhadap hasil UN siswa. Selain itu, hasil Penelitian yang dilakukan oleh Yurt (2014) menunjukkan bahwa Self-Efficacy berhubungan secara signifikan terhadap prestasi belajar siswa kelas 7 di Sekolah Konya.

Hasil uji hipotesis menunjukkan bahwa keterlibatan belajar matematika tidak berpengaruh secara signifikan terhadap prestasi belajar matematika pada taraf signifikansi 0,05. Hasil ini bertentangan dengan hasil penelitian yang dilakukan oleh Fung, et. al (2018) 
menunjukkan bahwa keterlibatan belajar berpengaruh positif terhadap hasil belajar matematika. Selain itu, Hasil penelitian yang dilakukan oelh Jie, et al (2020) menunjukkan bahwa keterlibatan belajar matematika siswa SMP di China berhubungan secara signifikan dengan prestasi belajar matematika pada keterlibatan belajar kognitif. Selanjutnya, hasil penelitian Lei et al (2018) menunjukkan bahwa ada korelasi yang cukup kuat dan positif antara keterlibatan belajar siswa dengan prestasi akademik. Hasil penelitian ini memberikan gambaran tentang tidak sesuainya dengan hipotesis yang telah dikemukakan. Sehingga, peneliti menyimpulkan bahwa banyak faktor yang menyebabkan keterlibatan belajar tidak berpengaruh terhadap hasil belajar Siswa kelas XI SMA Negeri 2 Bulukumba. Peneliti beranggapan bahwa masih banyaknya siswa yang tidak terlibat secara aktif dalam belajar matematika di sekolah. Selain itu, Hasil uji hipotesis menunjukkan bahwa tidak ada pengaruh positif dan signifikan efikasi diri melalui keterlibatan belajar matematika terhadap prestasi belajar matematika pada taraf signifikansi 0,05. Hasil ini bertentangan dengan hasil penelitian yang dilakukan oleh Ozkal (2019) menunjukkan bahwa self-efficacy berhubungan secara signifikan dengan prestasi belajar matematika melalui keterlibatan perilaku dan afektif dalam belajar matematika.

\section{Kesimpulan}

Berdasarkan hasil uji hipotesis dan pembahasan diatas, maka dapat disimpulkan bahwa efikasi diri berpengaruh positif dan signifikan secara langsung terhadap keterlibatan belajar matematika dan prestasi belajar matematika siswa kelas XI SMA Negeri 2 Bulukumba. Keterlibatan belajar matematika tidak berpengaruh secara signifikan terhadap prestasi belajar matematika dan memperlemah pengaruh efikasi diri terhadap hasil belajar matematika siswa kelas XI SMA Negeri 2 Bulukumba.

Hasil penelitian ini, kami menyarankan kepada guru khususnya guru matematika agar dalam proses pembelajaran matematika dikelas hendaknya guru memberikan umpan balik yang efektif sehingga dapat meningkatkan efikasi diri dan keterlibatan siswa dalam belajar matematika. Untuk penelitian selanjutnya kami menyarankan kepada peneliti di bidang ini untuk melakukan kajian sejauh mana pengaruh keterlibatan belajar terhada gaya belajar, usia, jenis kelamin, motivasi, prestasi awal atau kemampuan awal akademik siswa.

\section{DAFTAR PUSTAKA}

Alam, Syamsu. “Apa Itu Mathematics Self-Efficacy ?” Prosiding Seminar NasionaL 04 (2018): 269-77. https://www.journal.uncp.ac.id/index.php/proceding/article/view/1260.

Fung, F. "Student Engagement and Mathematics Achievement: Unraveling Main and 
Interactive Effects." Psychology in the Schools 55, no. 7 (2018): 815-31. https://doi.org/10.1002/pits.22139.

Güzin Mazman Akar, Sacize, Osman Birgin, Büşra Göksu, Kübra Uzun, Büşra Gümüş, and Elif Seval Yıldırım. "Matematik Dersine Bağlılık Ölçeği’nin Türkçeye Uyarlama Çalışması." Turkish Journal of Computer and Mathematics Education (TURCOMAT) 8, no. 1 (2017): 28-28. https://doi.org/10.16949/turkbilmat.286926.

Jie, Zhang Li, Zhou Ying, and Mo Zong Zhao. "THE RELATIONSHIP BETWEEN MATHEMATICS ATTITUDE , LEARNING ENGAGEMENT AND ACADEMIC" 3, no. 1 (2020): 24-36.

Kong, Qi Ping, Ngai Ying Wong, and Chi Chung Lam. "Student Engagement in Mathematics: Development of Instrument and Validation of Construct." Mathematics Education Research Journal 15, no. 1 (2003): 4-21. https://doi.org/10.1007/BF03217366.

Lei, Hao, Yunhuo Cui, and Wenye Zhou. "RELATIONSHIPS BETWEEN STUDENT ENGAGEMENT AND ACADEMIC ACHIEVEMENT : A META-ANALYSIS" 46, no. 3 (2018): 517-28.

Ozkal, Nese, Faculty Education, and Alanya Alaaddin. "Cypriot Journal of Educational” 14, no. 2 (2019): 190-200.

Pengelola Web Kemendikbud. "Hasil PISA Indonesia 2018: Akses Makin Meluas, Saatnya Tingkatkan Kualitas,” 2019. https://www.kemdikbud.go.id/main/blog/2019/12/hasil-pisaindonesia-2018-akses-makin-meluas-saatnya-tingkatkan-kualitas\#: :text=Hasil studi PISA 2018 yang,rata skor OECD yakni 487.\&text=Antusiasme para guru Indonesia termasuk,Albani\%2C Kosovo\%2C dan Korea.

Pusat Penilaian Pendidikan. "Laporan Hasil Ujian Nasional." Kemendikbud, 2019. https://hasilun.puspendik.kemdikbud.go.id/\#2019!smp!capaian_nasional!99\&99\&999!T \&T\&T\&N\&1\&!1!\&.

Sökmen, Yavuz. "The Role of Self-Efficacy in the Relationship between the Learning Environment and Student Engagement." Educational Studies 47, no. 1 (2021): 19-37. https://doi.org/10.1080/03055698.2019.1665986.

Sukoco, Heru, Arief Wismono, and Rusmilah. "Skala Mathematics Self-Efficacy Untuk Jenjang SMA (Mathematics Self-Efficacy For Senior High School/MSESc).” Prosiding Seminar Nasional Etnomatnesia, 2018, 752-60.

Suryanti, S., Y. Arifani, I. Zawawi, and N. Fauziyah. "Student's Engagement Behaviour and Their Success in Abstract Algebra: Structural Equation Modelling Approach." Journal of Physics: Conference Series 1188, no. 1 (2019). https://doi.org/10.1088/17426596/1188/1/012105.

Usher, Ellen L, and Frank Pajares. "Sources of Self-Efficacy in Mathematics : A Validation Study." Contemporary Educational Psychology 34, no. 1 (2009): 89-101. https://doi.org/10.1016/j.cedpsych.2008.09.002. 
Yurt, Eyüp. "The Predictive Power of Self-Efficacy Sources for Mathematics Achievement." Egitim ve Bilim 39, no. 176 (2014): 159-69. https://doi.org/10.15390/EB.2014.3443. 